\title{
Mutual admissibility of evidence and the European investigation order: aspirations lost in reality
}

\author{
Martyna Kusak ${ }^{1,2}$
}

Published online: 7 January 2019

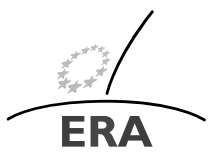

(C) The Author(s) 2019

EUROPÄISCHE RECHTSAKADEMIE ACADEMY OF EUROPEAN LAW ACADEMIE DE DROIT EUROPEEN ACCADEMIA DI DIRITTO EUROPEO TRIER - TREVES - TREVIRI

Abstract This article deals with the topic of mutual admissibility of evidence in the EU. It presents inability of the forum legit actum principle to overcome problems related to free movement of evidence and points out the ideas that can be undertaken in the future.

Keywords European investigation order $\cdot$ Mutual admissibility of evidence $\cdot$ Forum regit actum $\cdot$ Minimum standards

\section{Introduction}

The European Investigation Order (hereafter EIO) ${ }^{1}$ is a new legislative measure aimed at facilitating evidence-gathering in criminal matters in the EU, which is be-

\footnotetext{
${ }^{1}$ Directive 2014/41/EU of the European Parliament and of the Council of 3 April 2014 regarding the European Investigation Order in criminal matters, OJ L 130/1 (hereafter the EIO Directive).
}

The paper has been supported by grant PRO-2014/15/N/HS5/02686 awarded by the National Science Centre, Poland.

The author has been supported by the Foundation for Polish Science (FNP).

\section{Kusak}

m.kusak@amu.edu.pl

1 Adjunct Professor, Adam Mickiewicz University in Poznań, Poznań, Poland

2 Post-doc collaborator, Institute for International Research on Criminal Policy, Ghent University, Ghent, Belgium 
lieved to be more efficient than a freezing order ${ }^{2}$ or a European evidence warrant. ${ }^{3}$ An EIO is to be issued for the purpose of having one or several specific investigative measures carried out in the state executing the EIO with a view to gathering evidence. The instrument applies to all investigative measures aimed at gathering of evidence, ${ }^{4}$ as well as at obtaining evidence that is already in the possession of the executing authority (Article 1(1) of the EIO Directive).

The EIO, however, is not free from conceptual weaknesses which will hamper its cross-border efficiency. In particular, the Directive is not accompanied with rules facilitating mutual admissibility of evidence gathered using the EIO, which is the key to its effectiveness. Therefore, this article will clarify some features of the topic of mutual admissibility of evidence, and point out the ideas that can be undertaken in the future.

\section{Uncompleted path towards mutual admissibility of evidence in the EU}

The question of how to address the admissibility of evidence gathered in a crossborder context is of long standing both within the European Union and in the context of Council of Europe cooperation in criminal matters. ${ }^{5}$

The 1959 Convention $^{6}$ (often called a 'mother treaty'), which was originally the sole legal basis for mutual legal assistance between the EU member states, relied on the locum regit actum principle (Article 3), according to which any letters rogatory relating to a criminal matter are to be executed by the requested party in the manner provided by its own law. In other words, the locus regit actum principle assumes that the decisive element in determining the applicable law is the location of the evidence or the investigative measure. This concept, however, is incapable of overcoming differences between national procedures, as a result of which sometimes information gathered in a requested member state can not be used in the requesting state because the way the information was obtained in the former does not fit the national procedural requirements of the latter. ${ }^{7}$

\footnotetext{
${ }^{2}$ Council Framework Decision 2003/577/JHA of 22 July 2003 on the execution in the European Union of orders freezing property or evidence, OJ L 196/45.

${ }^{3}$ Council Framework Decision 2008/987/JHA of 18 December 2008 on the European evidence warrant for the purpose of obtaining objects, documents and data for use in proceedings in criminal matters, OJ L 350/72.

${ }^{4}$ Save for Art. 3 of the EIO Directive.

${ }^{5}$ The topic has also been widely discussed by academic scholars, see in particular: Vermeulen/De Bondt/Van Damme [15], pp. 254; Vermeulen [16], pp. 51; Armada [1], pp. 8-31; Bachmaier Winter [2], pp. 580-589; Daniele/Calvanese [3], pp. 354-391; Depauw [5], pp. 82-98; Gane/Mackarel [6], pp. 98119; Gless [7], pp. 121-130; Heard/Mansell [8], pp. 353-367; Lach [10], pp. 107-110; Ruggeri [12], pp. 231; Ryan [13], pp. 259; Spencer [14], 29-38.

${ }^{6}$ European Convention on Mutual Assistance in Criminal Matters, Strasbourg, 20.4.1959, European Treaty Series No. 30.

${ }^{7}$ Vermeulen [16], pp. 41-42.
} 
Therefore, in order to maximise the chances of evidence gathered abroad being admissible, a new 2000 EU Mutual Legal Assistance Convention ${ }^{8}$ provides a new approach - the forum regit actum principle (Article 4 of the 2000 Convention). According to this principle, a requested member state which is executing a request must comply with the formalities and procedures expressly indicated by the requesting member state. The reason for this provision is to facilitate the use of information gathered by mutual assistance as evidence in subsequent proceedings in the requesting member state. The words 'formalities and procedures' should be interpreted in a broad sense and may include, for example, the situation where a request indicates that a representative of the judicial authorities of the requesting member state or defence representative must be permitted to attend the taking of evidence from a witness. On account of the burden this might place on the requested member state, the requesting member state should set out only those formalities and procedures which are indispensable for its investigations. The requested member state can only refuse to give effect to the formalities and procedures in question where they are contrary to its fundamental principles of law or where the Convention itself expressly states that the execution of requests is governed by the law of the requested member state. ${ }^{9}$

Therefore, Article 4 of the Convention shifts the balance of mutual assistance so as to require where possible that assistance be provided in a manner requested by the requesting member state. This approach has been subsequently copied from mutual legal assistance instruments into mutual recognition instruments, namely to the freezing order (see Article 5.1 of the Freezing Order Framework Decision) and European evidence warrant (see Article 12 of the European Evidence Warrant Framework Decision).

Whilst the forum regit actum principle formed the basis for EU-cross border cooperation, the concept of mutual admissibility of evidence was put forward in the Tampere conclusions. This new approach assumes that evidence lawfully gathered by one member state's authorities should be admissible before the courts of other member states, taking into account the standards that apply there. ${ }^{10}$ The concept of mutual admissibility of evidence subsequently emerged in the programme of measures to implement the principle of mutual recognition (which states that the aim of orders for the purpose of obtaining evidence, is to ensure that evidence is admissible) ${ }^{11}$ and in the Green Paper of 2009 on obtaining evidence and securing its admissibility. ${ }^{12}$

At the time, however, the idea of mutual admissibility of evidence was more wishful thinking than a realistic concept. First of all, differences deriving from differing legal systems and approaches to evidentiary issues still exist between member states

\footnotetext{
${ }^{8}$ Convention of 29 May 2000 on Mutual Assistance in Criminal Matters between the Member States of the European Union, 12.7.2000, OJ C 197/1, hereinafter: the 2000 EU MLA Convention.

${ }^{9}$ See Explanatory Report on the Convention of 29 May 2000 on Mutual Assistance in Criminal Matters between the Member States of the European Union, 29.12.2000, OJ C 379/7, p. 11.

${ }^{10}$ European Council, Presidency Conclusions, Tampere, 15 and 16 October 1999, p. 36.

${ }^{11}$ Programme of measures to implement the principle of mutual recognition of decisions in criminal matters, OJ C 12, 15.1.2001, p. 10.

${ }^{12}$ Green Paper on obtaining evidence in criminal matters from one Member State to another and securing its admissibility, Brussels, 11.11.2009, COM (2009), 624 final.
} 
in the field of evidence gathering. ${ }^{13}$ This may lead to situations where, given the differences between national procedures, evidence gathered in one member state will not be admissible in another member state because the way the information was obtained does not fit the latter's procedural requirements. These differences, therefore, may have a negative impact on mutual trust between member states, raise questions as to the status of evidence gathered in the course of EU cross-border cooperation, and make the concept of mutual admissibility of evidence simply unrealistic. Secondly, it is doubtful whether the forum regit actum principle is in line with the philosophy of mutual recognition ${ }^{14}$ and capable of accommodating admissibility concerns in the EU. In the academic literature the following conceptual flaws and weaknesses of forum regit actum have been reported:

- forum regit actum does not involve a commitment to accepting the admissibility of evidence gathered in accordance with the principle, which means that a request to take certain formalities or procedures into account does not ensure that the effort applied in gathering evidence will be rewarded with admissibility;

- it has very limited effect on the level of admissibility due to the fact that it applies only in a one on one relationship and has no potential to ensure admissibility within the entirety of the EU;

- it lacks transparent rules in terms of the lawfulness of the way evidence is gathered;

- the forum regit actum principle applies only in the case of gathered evidence, meaning that already existing evidence cannot fall within its scope. ${ }^{15}$

Therefore, it is highly questionable whether the concept of mutual admissibility of evidence, as set in the Tampere conclusions, can be achieved by means of the forum regit actum principle.

Good news is that the Treaty on the Functioning of the European Union ${ }^{16}$ (hereafter TFEU) has offered an alternative to forum regit actum, opening the possibility of adopting minimum rules concerning, among other things, mutual admissibility of evidence Article 82(2) provides

'To the extent necessary to facilitate mutual recognition of judgments and judicial decisions and police and judicial cooperation in criminal matters having a cross-border dimension, the European Parliament and the Council may, by means of directives adopted in accordance with the ordinary legislative procedure, establish minimum rules. Such rules shall take into account the differences between the legal traditions and systems of the Member States. They shall concern: (a) mutual admissibility of evidence between Member States [...]'

Adoption of these rules would mean that, in the context of EU cooperation in criminal matters, evidence would have to be gathered according to commonly agreed min-

\footnotetext{
${ }^{13}$ Vermeulen [16], De Bondt/Van Damme [4], p. 254; Kusak [9], p. 243.; Ligeti [11], p. 1096; Ryan [13], p. 259.

${ }^{14}$ De Bondt/Vermeulen [4], p. 71, 72.

${ }^{15}$ Vermeulen [16], pp. 42-43.

${ }^{16}$ Consolidated version of the Treaty on the Functioning of the European Union, 26.10.2012, OJ C 326/1.
} 
imum standards, complemented by per se admissibility of evidence gathered in accordance with these. ${ }^{17}$

The idea of common minimum standards was subsequently addressed in the following policy documents:

- the Green paper on obtaining evidence in criminal matters from one Member State to another and securing its admissibility, ${ }^{18}$ which states:

'there is therefore a risk that the existing rules on obtaining evidence in criminal matters will only function effectively between Member States with similar national standards for gathering evidence (...) The best solution to this problem would seem to lie in the adoption of common standards for gathering evidence in criminal matters' (see pp. 5-6)

- the Communication from the Commission to the Council and the European Parliament Communication on the mutual recognition of judicial decisions in criminal matters and the strengthening of mutual trust between Member States, ${ }^{19}$ point 3.1.1.3 of which on p. 7 states:

'Cross-border court actions entail the possibility for evidence gathered in one Member State to be used in another. But respect for defence rights entails certain minimum rules on the gathering of evidence being observed throughout the Union. The Commission will issue Green Paper in 2006 on the basis of a study proposing a minimum harmonisation exercise regarding standards for the gathering and disclosure of evidence, admissibility criteria and possible exceptions. Following in-depth consultation on the basis of these two Green Papers, the Commission will present a proposal for a Framework Decision on the presumption of innocence and minimum standards on the gathering of evidence'

- the Communication from the Commission to the European Parliament and the Council An area of freedom, security and justice serving the citizen, ${ }^{20}$ point 4.4 .2 of which on p. 17 states

'The Union is establishing a comprehensive system for obtaining evidence in cross-border cases (...) Other avenues to be explored are (...): minimum principles to facilitate the mutual admissibility of evidence between countries, including scientific evidence.'

- the Communication from the Commission to the European Parliament, the Council, the European Economic and Social Committee and the Committee of the Regions Delivering an area of freedom, security and justice for Europe s citizens. Action Plan Implementing the Stockholm Programme, ${ }^{21}$ which mentions (at p. 18 thereof)

\footnotetext{
${ }^{17}$ Vermeulen [16], p. 45.

${ }^{18}$ Brussels, 11.11.2009, COM (2009) 624 final.

${ }^{19}$ 19.5.2005, COM (2005) 195 final.

${ }^{20}$ Brussels, 10.6.2009, COM (2009) 262 final.

${ }^{21}$ Brussels 20.4.2010, COM (2010) 171 final.
} 
'Action: Legislative proposal to introduce common standards for gathering evidence in criminal matters in order to ensure its admissibility.'

Notwithstanding Article 82(2) TFEU and the above-mentioned policy documents, the EU has not taken any steps forward and still operates under the assumption that domestic incompatibilities between national rules for evidence-taking and, accordingly, the concept of mutual admissibility of evidence, may be accommodated by the forum regit actum principle. Therefore, the EIO directive still states that 'the executing authority shall comply with the formalities and procedures expressly indicated by the issuing authority unless otherwise provided in this directive and provided that such formalities and procedures are not contrary to the fundamental principles of law of the executing state'. (Article 9(2)).

Article 9(2) of the EIO Directive is not just the lack of progress. Introducing an instrument aimed at evidence-gathering without standards ensuring its admissibility, as provided for in Article 82(2) TFUE, is a step backward and missed opportunity to finally shape the so far non-existent concept of mutual recognition of evidence. Once the European Investigation Order is in force, the EU legislative focus on evidence will be gone and it will be difficult to re-address it in the nearest future.

\section{The concept of common EU minimum standards for evidence-gathering}

The biggest added value of the concept of common minimum standards is that, in contrast to the forum regit actum principle, it has the potential to finally tackle admissibility concerns in the EU. ${ }^{22}$

First of all, common EU minimum standards correspond with the mutual recognition philosophy by enhancing mutual trust between member states as to how evidence is issued and gathered.

Moreover, minimum standards have the potential to accommodate the weaknesses of forum regit actum. First, gathering of evidence under commonly agreed minimum standards would be complemented with per se admissibility, which resolves the problem of uncertainty of forum regit actum and facilitates cooperation since the rules would not vary depending on the member states concerned. Secondly, due to the fact that common standards would be applicable within the entirety of the EU, the evidence gathered in accordance with these would enjoy per se admissibility status in all member states, not only in one-to-one relations as in the case of forum regit actum. Thirdly, minimum standards would consist of transparent rules as to the way evidence is gathered, which could do away with dilemmas as to the lawfulness of the procedure.

Article 82(2) TFEU permits the introduction of minimum standards where such standards are necessary to facilitate EU cross-border cooperation, which means that evidence gathered in a merely domestic context falls outside this scope. Due to the fact that the European Investigation Order also applies to already extant evidence,

${ }^{22}$ Vermeulen [16], pp. 44-45. 
there is a risk that it would cause a frustrating distinction in the admissibility of evidence gathered in the EU cross-border context (under commonly agreed standards) and in a domestic context (gathered under domestic rules and transferred to the issuing state). This problem could be resolved by introducing minimum standards for all evidence-gathering, which would mean their application also in merely domestic proceedings. This idea seems realistic since the current adoption of a number of instruments in criminal procedures shows that member states are not too strict in interpreting Article 82(2) TFEU and adopt minimum rules that are applicable also in a merely domestic context. ${ }^{23}$

Arriving at common EU minimum standards would require balancing the search for overcoming national diversities, on the one hand, and accepting the fact of international diversity on the other. Since these standards are to be 'minimum', they should be based on or, at least, drafted in line with the common fundamental rights and norms developed by the European Court of Human Rights in Strasbourg. For the same reason, member states would still be able to extend these standards in order to provide a higher level of protection. However, mutual recognition of evidence across the EU would be achieved by following the commonly agreed minimum, irrespective of upgraded domestic rules.

\section{Common EU minimum standards for evidence-gathering: a feasible scenario?}

The concept of EU minimum standards and its impact on the mutual recognition of evidence, even though abandoned by the EU, have been investigated by academic scholars. ${ }^{24}$ For instance, a study on telephone tapping and house searches based on six sets of laws ${ }^{25}$ proved the feasibility of coming to various types of common EU minimum standards. The research first detected the factors that might hamper mutual recognition of evidence gathered from telephone tapping and house search and, secondly, derived minimum standards with regard to these factors with a view to enhancing mutual trust between member states regarding methods of evidence-gathering. The research showed that:

- irrespective of the name tag of the issuing authority, if member states ensured that bodies appointed to grant both measures guaranteed minimum protection against arbitrariness, the evidence gathered upon their decisions could constitute per se admissible evidence, even if in a similar domestic case the measure would require the involvement of a different body (e.g., a judicial body);

- if member states ensured the availability of both measures with regard to cases concerning the offences listed in Article 2(2) of the Council Framework Decision of

\footnotetext{
${ }^{23}$ Vermeulen [16], 44-47; Kusak [9], 31-33.

${ }^{24}$ Vermeulen/De Bondt/Van Damme [15], pp. 254; Vermeulen [16], pp. 51; Depauw [5], pp. 82-98; Kusak [9], pp. 243.

${ }^{25}$ The doctoral research was carried out at Adam Mickiewicz University and at Ghent University. The entire body of research is published as a book entitled Mutual admissibility of evidence in criminal matters in the EU. A study of telephone tapping and house search, Maklu (2016).
} 
13 June 2002 on the European arrest warrant and the surrender procedures between Member States 26 it would do away with discussions about the mutual allowance of the measures and result in per se admissible evidence gathered upon common minimum materiae standards. (In cases not concerning these offences, the member states might still subject the execution to the domestic admissibility requirement);

- mutual trust could also be significantly enhanced by introducing the same minimum standards with regard to places and time frameworks in which the measures may be conducted;

- if member states accepted a mutual approach to personae, including the scope of persons concerned and groups granted special treatment, evidence gathered through these persons would constitute per se admissible evidence and ensure a common level of protection for these persons in the EU;

- persons whose rights were infringed could be granted common minimum standards related to effective legal remedies, although these remedies might differ between member states and might apply at different stages of proceedings. The feasibility of effectuating these remedies could be enhanced by adopting common standards for the notification of the measures.

The study also revealed that not all incompatibilities between member states require unification at EU level, but only these which may have a negative effect on mutual trust. These types of measures should be selected on the basis of their intrusive character, the questionable admissibility of evidence gathered, or expected differences between member states that could potentially obstruct mutual admissibility of evidence. It is noteworthy that, thus far, progress towards common standards has also been made with regard to expert, ${ }^{27}$ forensic and electronic evidence. ${ }^{28}$

The outcome of the studies reveals both the academic feasibility of arriving at EU minimum standards for two measures, and its positive impact on the idea of mutual recognition of evidence. Hopefully, it will also give rise to further study and legislative initiatives on this topic. These minimum standards could subsequently be adopted by means of a directive regarding minimum standards for gathering of evidence, which could finally shape the concept of mutual recognition of evidence in criminal matters in the EU.

\section{How to deal with admissibility of evidence gathered using the EIO?}

Due to the lack of EU common rules, admissibility of evidence gathered using the EIO is still governed by the domestic law of the member states concerned (both the issuing, which seeks for evidence, and the executing, which may subsequently use it in domestic proceedings).

In this context it is noteworthy to mention that, even if all member states develop complex and protective domestic approaches to the admissibility of evidence, these domestic rules are not scrupulously applied when it comes to evidence gathered from

\footnotetext{
${ }^{26}$ OJ L 190/1.

${ }^{27}$ De Bondt/Vermeulen [4], pp. 71-72.

${ }^{28}$ Depauw [5], pp. 82-98.
} 
abroad. First, this follows from the fact that member states usually lack domestic rules regarding the admissibility of evidence collected abroad (the example of legislation which directly address admissibility of foreign evidence, which differs from domestic standards, is Poland and its Article 587 of the Code of Criminal Procedure. The article concerned accepts any foreign items provided the manner of conducting the procedure is not contrary to the legal order of the Republic of Poland). Secondly, it is safe to say that some member states are more tolerant and flexible in their approaches to foreign evidence.

Leaving member states without common rules enhancing the admissibility of evidence gathered using an EIO may result in confusion and problematic distinctions between the status of evidence gathered in a cross-border EU context and domestically. Moreover, it gives rise to a risk that member states will take varying approaches to the issue, which might involve the following:

- relying on lex locus legislation and using foreign requirements with regard to admissibility of evidence;

- relying on lex forum legislation and using the same model of control that applies to evidence gathered nationally;

- limiting the domestic model of control to general principles, such as the legal order or fundamental rights;

- ignoring both the foreign and domestic models of control and automatically recognising the evidence as regular. ${ }^{29}$

Despite the lack of common standards, member states arguably ought not to exclude evidence gathered under different rules to those provided for under its domestic law. In case of doubt, the decision as to whether such evidence will nonetheless be admissible could be made on the basis of the balancing test verifying the impact of evidence on fundamental EU rights, especially the right to a defence, in view of determining the fairness of the procedure and its compliance with Article 6 of the European Convention of Human Rights.

\section{Conclusions}

The EU, when developing the EIO directive, did not take advantage of Article 82(2) TFEU which allows for the introduction of common EU minimum standards facilitating the admissibility of evidence. Instead of this, the EIO still relies on the forum regit actum principle, which has questionable potential to ensure mutual recognition of evidence in the EU. Therefore, there is a risk that the existing rules on obtaining evidence in criminal matters will only function effectively between member states with similar national standards for evidence-gathering.

Operating under common EU minimum standards would introduce a new system of admissibility for evidence gathered in a cross-border EU context. It would mean breaking with the forum regit actum principle and basing the use of foreign evidence on commonly agreed, minimum procedural requirements derived from fundamental rights. Applying these standards to evidentiary measures in the domestic context

${ }^{29}$ Kusak [9], pp. 169-174. 
could also facilitate the use of the EIO with regards to the transfer of already existing evidence.

The reality, however, is that practitioners are still confronted with case-by-case efforts to enhance mutual admissibility of evidence (by applying the forum regit actum principle), and with questions of admissibility triggered by incompatibilities in evidentiary proceedings.

Publisher's Note Springer Nature remains neutral with regard to jurisdictional claims in published maps and institutional affiliations.

Open Access This article is distributed under the terms of the Creative Commons Attribution 4.0 International License (http://creativecommons.org/licenses/by/4.0/), which permits unrestricted use, distribution, and reproduction in any medium, provided you give appropriate credit to the original author(s) and the source, provide a link to the Creative Commons license, and indicate if changes were made.

\section{References}

1. Armada, I.: The European investigation order and the lack of European standards for gathering evidence. Is a fundamental rights based refusal the solution? New J. Eur. Crim. Law 6(1), 8-31 (2015)

2. Bachmaier Winter, L.: European investigation order for obtaining evidence in the criminal proceedings. Study of the proposal for a European directive. Z. Int. Strafrechtsdogmatik 9, 580-589 (2010)

3. Daniele, M., Calvanese, E.: Evidence gathering. In: Kostoris, R.E. (ed.) Handbook of European Criminal Procedure, pp. 354-391. Springer, Berlin (2018)

4. De Bondt, W., Vermeulen, G.: Free movement of scientific expert evidence in criminal matters. In: Cools, M., et al. (eds.) EU Criminal Justice, Financial and Economic Crime: New Perspectives, pp. 69-83. Maklu, Antwerpen-Apeldoorn-Portland (2011)

5. Depauw, S.: A European evidence (air)space? Taking cross border legal admissibility of forensic evidence to a higher level. Eur. Crim. Law Rev. 1, 82-98 (2016)

6. Gane, C., Mackarel, M.: The admissibility of evidence obtained from abroad into criminal proceedings - the interpretation of mutual legal assistance treaties and use of evidence irregularly obtained. Eur. J. Crime Crim. Law Crim. Justice 4(2), 98-119 (1996)

7. Gless, S.: Free movement of evidence in Europe. In: Deu, T.A., Inchausti, F.G., Hernen, M.C. (eds.) El derecho procesal penal en la Unión Europea. Tendencias actuals y perspectivas de futuro, Madrid, pp. 121-130 (2006)

8. Heard, C., Mansell, M.: The European investigation order. Changing the face of evidence gathering in EU cross border cases. New J. Eur. Crim. Law 2(4), 353-367 (2011)

9. Kusak, M.: Mutual Admissibility of Evidence in Criminal Matters in the EU. A Study of Telephone Tapping and House Search p. 243. Maklu, Antwerpen-Apeldoorn-Portland (2016)

10. Lach, A.: Transnational gathering of evidence in criminal cases in the EU de lege lata and de lege ferenda. In: EUCRIM 3, pp. 107-110 (2009)

11. Ligeti, K. (ed.): Toward a Prosecutor for the European Union. Volume 1. A Comparative Analysis p. 1096. Hart Publishing, Oxford and Portland, Oregon (2013)

12. Ruggeri, S. (ed.): Transnational Evidence and Multicultural Inquiries in Europe p. 231. Springer, Berlin (2014)

13. Ryan, A.: Towards a System of European Criminal Justice. The Problem of Admissibility of Evidence. Routledge, London (2014)

14. Spencer, J.R.: The concept of 'European Evidence'. ERA Forum 4(2), 29-38 (2003)

15. Vermeulen, G., De Bondt, W., Van Damme, Y.: EU Cross Border Gathering and Use of Evidence in Criminal Matters. Towards Mutual Recognition of Investigative Measures and Free Movement of Evidence? Maklu, Antwerpen-Apeldoorn-Portland (2010)

16. Vermeulen, G.: Free gathering and movement of evidence in criminal matters in the EU. Thinking beyond borders, striving for balance. In: Search of Coherence. Maklu, Antwerpen-Apeldoorn-Portland (2011) 